\title{
Prospects and constraints of formal rice seed systems in Nepal S Sapkota ${ }^{*}$ PP Regmi**, S Pandey*, B Tripathi ${ }^{* *}$ and SK Sah ${ }^{* *}$
}

\begin{abstract}
Rice (Oryza sativa) is the main crop of Nepal. Farmers in Nepal mostly use seed from their stock in the form of informal seed systems which is around $92.3 \%$ of total seed requirements. In Nepal, formal seed of rice is distributed mostly by public institutions and very nominal amount by private seed dealers. Unavailability of quality seed of preferred variety is the key issue for rice seed systems. This study tries to attempt to address existing rice seed supply systems in Nepal thereby understanding its opportunities and constraints. The study was undertaken by collecting information from various documented sources and primary data from the household survey done at Chitwan and some seed related institutions during 2010/11. Formal and the informal are the two dimensions of the seed system for rice. Farm saved seed and farmers- to- farmers exchange of seed are informal seed system whereas private seed dealers and public institutions' involvement in the seed sector are formal seed systems. Due to dominant of informal seed systems, there is the low seed replacement rate of $8.7 \%$ for rice. Nevertheless, breeder seed is solely produced by different Research Centers of Nepal Agriculture Research Council (NARC), whereas foundation seed is produced by NARC Research Centers and other institutes as well. This amount of source seed does not seem enough to cover rice areas of the country. To tackle problem of seed insufficiency, quality of source seed should be maintained by public institutions aside from creating awareness to farmers by service providers about the importance of producing certified seed by using foundation seed in farmers' field.
\end{abstract}

Key words: Rice, seed system, prospects, constraints

\section{Introduction}

Nepal is rich in agro biodiversity as a result of its diverse farming systems, extreme variation in micro- agro ecological niches and varied socio-cultural settings (Gauchan et al., 1999). Agro-ecological variations even within a small geographical area of the country make favor for diversifying agricultural opportunities.Agriculture is mainstay of the country and contributing to $32.4 \%$ of the total Gross Domestic Product (GDP) during 2008/09 (MOF, 2009). Rice (Oryza sativa) is a staple crop of Nepal and contributes $20 \%$ to GDP and $58 \%$ to AGDP (Bhatta, et al., 2008). Total area of rice is estimated to $1,549,262$ ha with

\footnotetext{
* NARC, Khumaltar, sudhasapkota@hotmail.com

** IAAS, Rampur

* IRRI, Philippines

$\therefore$ IRRI-Nepal
} 
productivity of $2.98 \mathrm{t} / \mathrm{ha}$. As the seed rate of rice is $50 \mathrm{~kg} / \mathrm{ha}$, the required seed is 77,463 t/year (CBS, 2010). Area, production, and productivity of rice are fluctuating every year. The area, production and yield of rice in 1968/69 was 1162000 (ha), 2178000 (t) and 1874 t/ha which has increased to 1555940 (ha), 4523693 (t) and $2907 \mathrm{Kg} / \mathrm{ha}$ in 2008/2009, respectively. Thus it shows an increment of about $34 \%$ in area, $108 \%$ in production and $55 \%$ productivity in $2008 / 09$ over $1968 / 69$. About $65 \%$ populations of the country are engaged in agriculture. Although a large chunk of people are working in agriculture nowadays, it is one of the imported agricultural products with over 7.5 million US dollar being annually used for import (Sapkota, et al., 2010 and Shrestha, 2007).

Rice, maize and wheat are the major important cereals of Nepal. But underutilized crops such as millet (finger, foxtail) and sorghum are the major food commodities of hills. However, due to high demand of rice in hilly districts, various donor agencies in collaboration with local I/NGOs are distributing rice and other non-rice seeds. Among various inputs, seed is one of the principal factors that govern return from almost all agriculture-based technological innovations. Seeds also transfer the genetic potentiality to regenerate to new crop from research institute to farming community. Timely availability of quality seed in a suitable specific location can give high yields to farmers that can contribute to reduce the pervasive poverty. It is observed that half the yield gains in major crops in last 50 years could be attributed to the introduction of new cultivars (Sapkota, 2010). Up to 2010, Nepal Agricultural Research Council (NARC) has released 60 different types of rice varieties. But, the trend of rice production has not been sufficiently increased. This paper is intended to outline and review the context of seed systems in Nepal. Why the farmers are disinclined to replace the seed is the focus of the study. The overall objectives of the study are to identify the prospects and constraints of rice seed supply system in Nepal in general and Chitwan in particular.

\section{Methodology}

The study is based on both primary as well the secondary data and the information. Key informant survey (KIS), personal interview and household survey were applied to collect primary information. A number of agricultural institutions mainly, Nepal Agricultural Research Council (NARC), National Seed Company (Governmental Seed Company) and Everest Seed Company (Private Seed Company) are involved in seed sector of Nepal were visited to collect primary as well secondary data from institutional level. Policy level information was collected by reviewing the policy papers published by concerned organization. Consisting, (KIS) were done with the key persons involved in seed production to delivery practices. Seventy farm households from Chitwan were visited to collect information at farm level. As well, Farmers' Group Discussions (FGD) was carried out. Literature and desktop reviews were the major sources to collect the secondary information. Index of importance was computed by using the following formula to rank the issues.

\section{Where;}

$\mathrm{I}_{\mathrm{imp}}=\sum(\mathrm{sifi} / \mathrm{N})$ 
Where,

$\mathrm{I}_{\text {imp }}=$ Index of importance

$\sum=$ Summation

$\mathrm{si}=$ scale value (Value has been set for three levels)

$\mathrm{fi}=$ Frequency of importance given by the respondents

$\mathrm{N}=$ Total numbers of respondents

The formula is used in (Neuman, 2007 as well in Timsina, et. al, 2009)

SPSS and the EXCEL was the software packages were used to analyze the data.

\section{Result and discussion}

Definitions of some terms are used because some terminologies are newly coined and for the first time in the text attempt has been made to define those connotation, which are used below:

\section{Type of rice seed}

Rice seed is orthodox seed which needs well drying and desirable storage structure for proper germination. Therefore, it required additional practices to maintain the minimum quality standards.

\section{Seed supply system}

Seed supply systems are an association of formal and informal channels by which farmers meet their total seed requirements each year (Turner, 2010). However, the actual partition varies widely between different crops and countries, depending on the economic circumstances.

\section{Institutions involved in seed system}

The term "institution" refers to the organized formal sector, as Nepal Agricultural Research Council (NARC) and National Seed Company (NSC) which have local, national, and in some crops, global dimensions and having common motto. In contrast, the informal seed system is normally localized at the farm or community level and has relatively little organizational tendency without rules and regulations but with higher socio-cultural influence on the barter system.

\section{Seed system}

Seed system depicts a whole scenario of seed production as well as supply. Formal and informal are the two seed delivery system prominently existing in Nepal. The figure 1 depicts the formal institutional set up for the delivery of seed. NARC is a governmental apex body mandated for the production of rice breeder seed (BS). Its network has covered 54 different districts out of 75. It produced breeders as well the foundation seed (FS). But a large chunk of breeder seed goes to NSC. The NSC distributes the breeder seed and multiplies up to improved seed (IS) at farmer's level. Consequently Private Seed Companies 
(PSC) also receive the breeder seed and multiply up to improved seed. NSC is supplying only $3-5 \%$ cereal seed, out of total seed requirement of the country.

Department of Agriculture (DoA) is mandated for the extension of seed and covers all districts. Since the Ninth Five Year Plan (1998/99 to 2001/03), District Seed Self Sufficiency Program (DISSPRO) was initiated with the motive to encourage and strengthen local level seed production and marketing to meet local and district level seed demand. Community Based Seed Production program is a program jointly organized by DoA, NARC and farmers' group (FG) for cereal production. Community Based Seed Production Program was a program based on bottom to top approach. About 4,500 ton of cereal seeds annually has been produced by these approach. Approach is composed of subsidies on seeds, creation of revolving funds, group/social network, training and visit ( $\mathrm{T} \& \mathrm{~V}$ ) farmers to farmers ( $\mathrm{F}$ to $\mathrm{F}$ ) exchange.

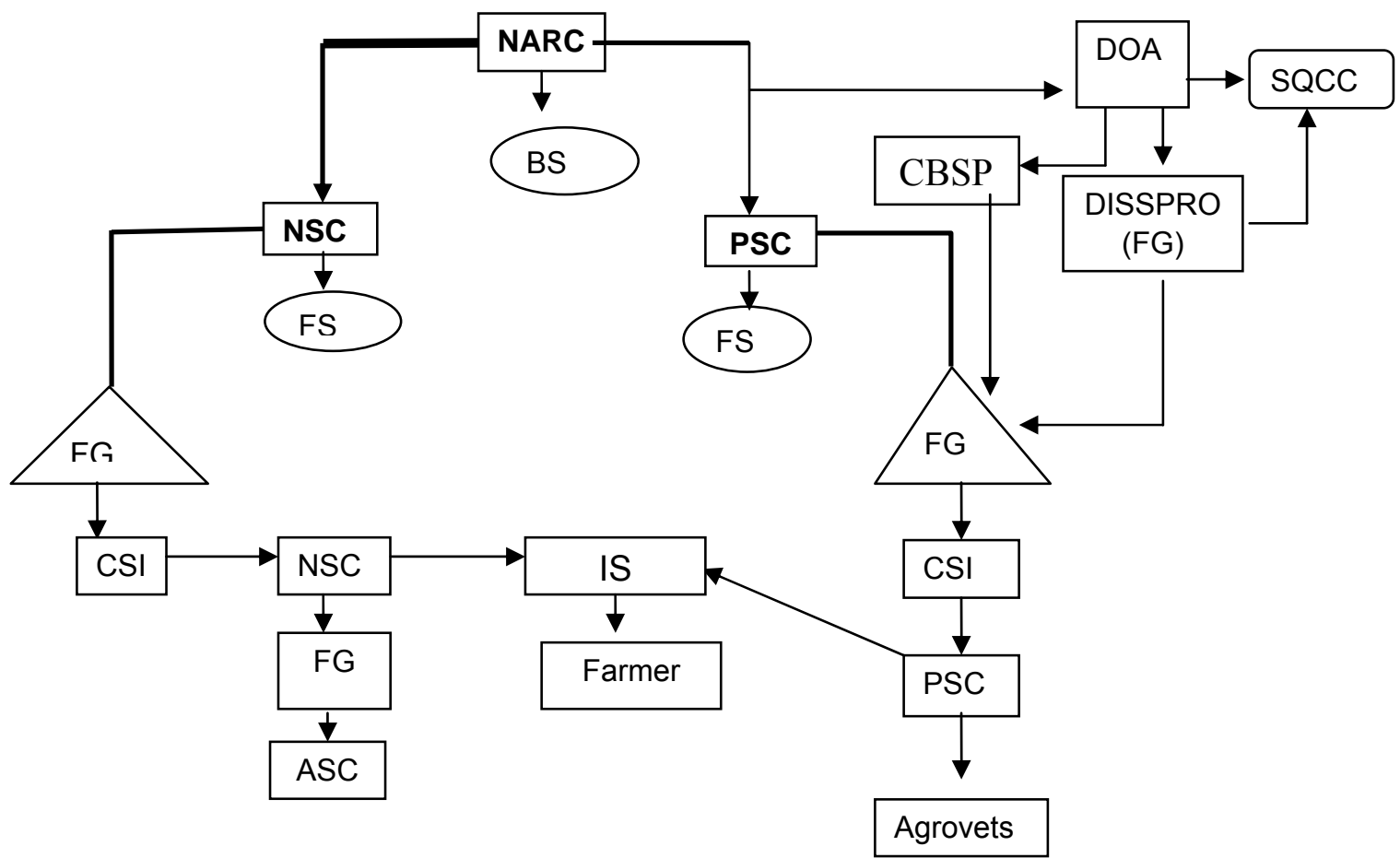

Figure 1. Institutional setup for formal seed system in Nepal

NARC : Nepal Agricultural Research Council

FS : Foundation Seed

FG : Farmers Group

PSC : Private Seed Company

ASC : Agriculture Sub Center

DISSPRO : District Seed Self sufficiency Program
BS : Breeder Seed

DOA : Department of Agriculture

CSI : Certified Seed First Generation

IS : Improved Seed

CBSP : Community based Seed Production SQCC : Seed Quality Control Center 
Due to various mandatory reasons of the department, after becoming Nepal the member of WTO, Seed Quality Control Center (SQCC) is independently established to control the quality of seed under the Ministry of Agriculture and Cooperatives. Different Regional Seed Testing Laboratories have been established by the Department of Agriculture (DoA) to provide services of seed testing to the general public. These are the institutional set up of government for production and delivery of seed. The ultimate goal of these institutions is to produce, deliver and facilitate the consumption of quality seed for enhancing the production and reduction of poverty. Until the year 2010, about 60 different varieties of rice have been released by National Variety Releasing System in Nepal. However, the trend of production is stagnant since last six years.

\section{Seed market}

Seed market of Nepal has two different components which directly affected the organization of the seed supply. Volume and value of the seeds are two different components of a crop of which could influence on the seed trade. The potentiality of a seed counts how much to regenerate or further involvement in the market for further production. In other words, how the seed of a crop get high turnover rate or commercialized with in a certain period of time. Normally the seeds of cereal crops with high sowing rate and less value crops have less command in the seed trade. While those such as vegetables, with low sowing rates and high output values can command a good market price and commercialize (Turner, 2010).

A further consequence of seed market of Nepalese scenario is presented in Figure 2. This reflects formal as well as informal two branches of the seed system and how they composed with different components.

\section{Seed market}

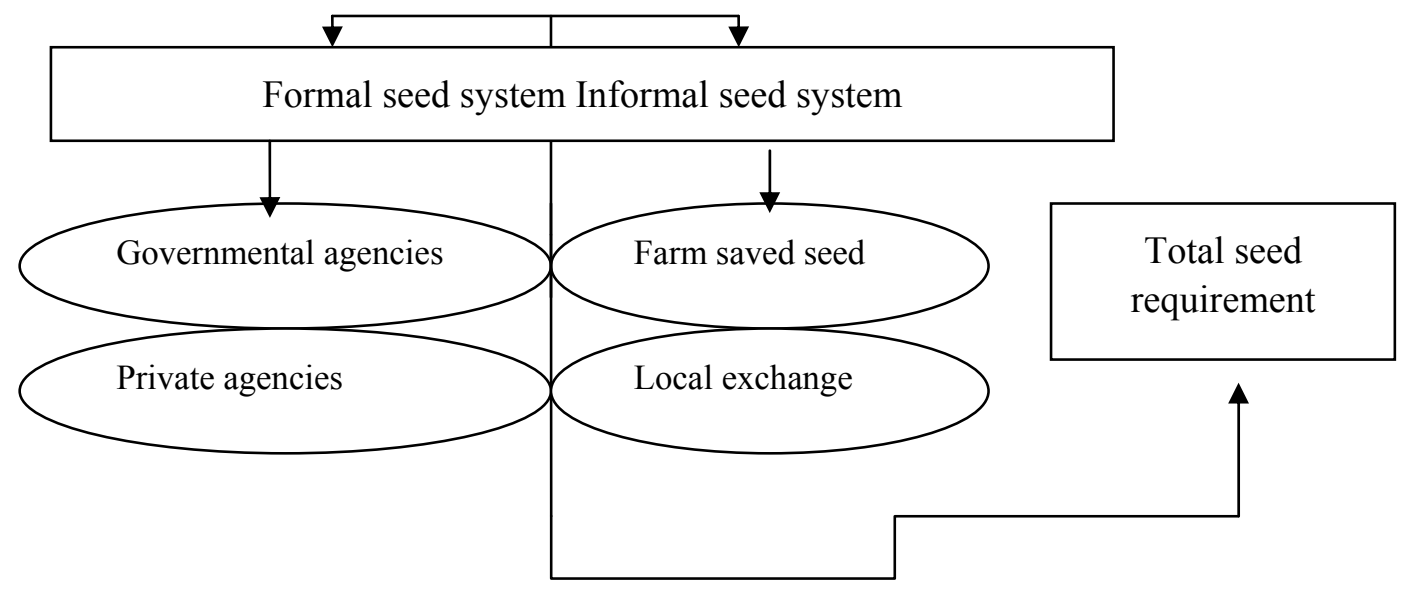

Figure 2. Components of seed supply system 
Question may arise whether the strong set up of institutional components are delivering the huge mass of seed to farmers level or not? How this institutional set up is working with various stakeholders to fulfill the need.

\section{Need for the quality seed distribution by different mechanisms}

Quality seed is considered as the basic, critical and cheapest input for enhancing productivity. Quality seed for a specific location can contribute high yield in farm level which can reduce the pervasive poverty. Half the yield gains in major crops in last 50 years can be attributed to the introduction of new cultivars. But the quality of a newly developed variety plays a major role in the extended adoptability of a new cultivar. Till the year 2010, NARC has released 60 different types of rice varieties. But the rice production trend shows almost stagnant for the last five years. Therefore, a question arise those variety might show a good varietal effect but what about the quality attributes.

An example could be taken with the neighboring countries as Bangladesh and India; where informal institutions are prominently working in seed delivery. In Bangladesh only 5 to $6 \%$ of the total demand of 0.8 million tons every year is fulfilled by formal institutions (Sapkota et al; 2010). Scientists recommend that farmers should replace their seeds with quality certified seed once in every three years for obtaining high yield potentials. In Andra Pradesh, India, where seed industry is highly developed farmers buy $46 \%$ of seed every year. Experiment conducted in the Philippines and Thailand shows good quality seed could increase rice yield from 8 to $10 \%$. It is noted that where the seed replacement rate is high the average rice yield is high. (Sapkota, et al.2010). However to change the seed frequently, good quality seed in desired amount should be available in time.

\section{A scenario of seed supply and demand}

Rice seed requirement of a country is 77,463 t/year (CBS, 2010). Table 1 depicts only 6,768 t/year had been supplied by the formal institutions. Mainly the private institutions are playing leading role. Table 1 shows the seed supply status by different institutions in Nepal.

Table1. Seed supply and the status of Seed Replacement Rate (SRR) in Nepal

\begin{tabular}{lccccccc}
\hline \multirow{2}{*}{ F/Y } & \multirow{2}{*}{ Area(ha) } & \multicolumn{9}{c}{ Seed Supplied by (t) } & Total (t) & $\begin{array}{c}\text { SRR } \\
(\%)\end{array}$ \\
\cline { 3 - 7 } & & NARC & DOA & NSC & PSC & & (\%) \\
\hline $2005 / 6$ & 1549447 & 300 & 1746 & 776 & 1812 & 4643 & 5.99 \\
$2007 / 8$ & 1549262 & 255 & 1750 & 897 & 2169 & 5071 & 6.55 \\
$2008 / 9$ & & - & - & - & - & 6768 & 8.7 \\
\hline
\end{tabular}

Source: SQCC, 2009

Seed Replacement Rate is one of the principle factors to increase the production level and Nepal has only $8.7 \%$. Where as India has $12 \%$. Only $7 \%$ of the total demand of the seed is 
fulfilled by formal institutions rest $93 \%$ of total seed requirement is fulfilled by informal system.

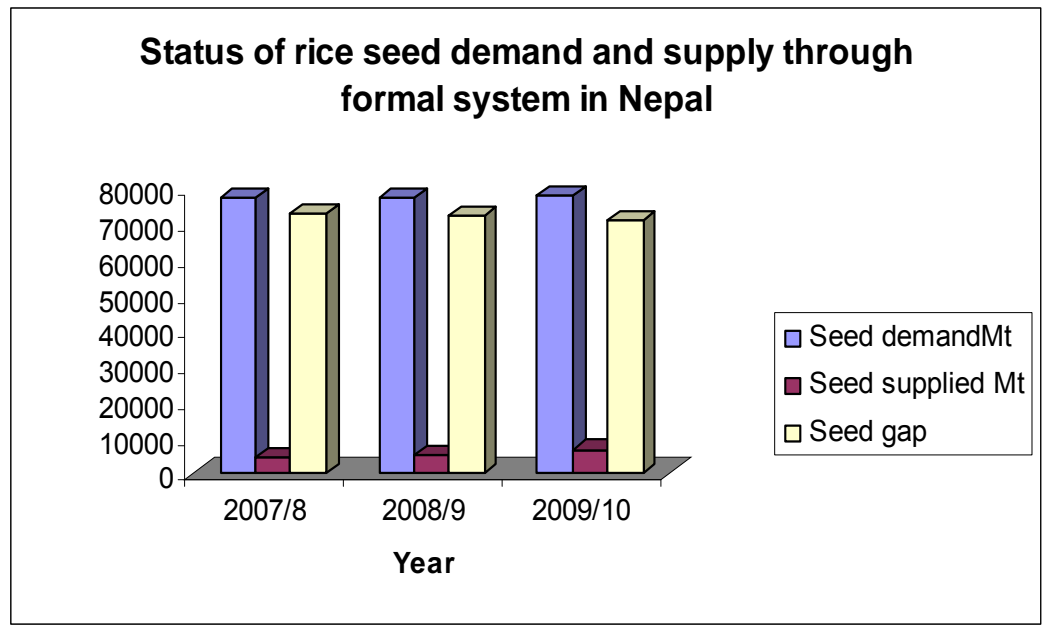

Figure 3. Seed demand and supply situation in Nepal

Source : SQCC, Government of Nepal, 2010

The status of rice seed demand and supply through formal institution shows a huge gap. To become a inbred seed to be used it has to passed through different steps such as crossing of plant, breeder seed, foundation seed, certified first generation, certified second generation to improved seed. Normally these steps are completed in 9 to 13 years. Mid hills of Nepal occupies nearly $25 \%$ of the total rice area of the country. $80 \%$ area of mid-hill is covered by improved rice varieties (Uprety et al, 2009). The most popular variety in this region is khumal 4, and the major problems in this variety are the lodging in fertile soil and highinput conditions. Therefore, farmers demanded non-lodging varieties with similar quality traits of Khumal 4 and that fit well in the prevailing rice-wheat cropping system. The Agriculture Botany Division, NARC thus developed Khumal 8 derived from a cross between Jumli Marsi (a local landrace for the high altitude) and IR36 (released by the National Seed Board for general cultivation in 2006) (Uprety et al 2009). National Seed Company is the governmental seed company and Everest Seed Company, a private seed company, is the two different companies working to produce foundation to improved seed of rice. Researchers visited to find out the scenario of seed dilemma of the hilly reason. During the field survey, farmers reported on the problem of seed borne diseases in foundation seed with infection of foot rot and neck blast complexes. Therefore, innovative farmers are reluctant to take the seed of khumal-8. Table 2 shows the target set by government, which is not sufficient to fulfill the seed demand of the country. 
Table 2. Target and the achievement of breeder seed production of rice of NARC.

\begin{tabular}{llccc}
\hline F/Y & Rice seed type & Target $(\mathrm{t})$ & Achievement $(\mathrm{t})$ & Achievement $(\%)$ \\
\hline $2007 / 08$ & Breeder seed & 7.7 & 7 & 92.4 \\
& Foundation seed & 309.8 & 203.8 & 65.8 \\
$2005 / 6$ & Breeder seed & 7.8 & NA & NA \\
& Foundation seed & 295.2 & NA & NA \\
$2004 / 5$ & Breeder seed & 5.67 & 11.2 & 198.2 \\
& Foundation seed & 314.7 & 408.2 & 129.7 \\
$2003 / 4$ & Breeder seed & 5.4 & 6.6 & 122.2 \\
& Foundation seed & 295.0 & 341.4 & 115.7 \\
$2002 / 3$ & Breeder seed & 5.5 & 5.4 & 99.6 \\
& Foundation seed & 289.0 & 295 & 102 \\
\hline
\end{tabular}

Source : Annual report (NARC, 2002- 2008)

In the situation, where the target set by government to produce breeder seed of rice is low, unplanned and unmanaged food security program lead to distribution of seed is the result of harvest with no grains. Not only the seed distributed by FAO in Western mid-hills but the rice varieties Chandannath-1 and Chandanath-3 distributed by governmental institutions were showing some unfilled grains and early dough stage resulting low yield (Sapkota et al 2010).

Improvement of the institutional norms and the policy issues are problems associated with rice, which are listed below and is limited to the problem of Chitwan district only. Chitwan district has a large number of Private Seed Companies, Commodity Program of NARC and the network of DOA. Table 3 shows the most prominent problem in farmers' level is unavailability of quality seed on time and not in sufficient quantity. Therefore; farmers are forced to keep their own saved seed for cultivation.

To depict the problems associated with production of seed in farmers' level, the index was constructed. To sum up or combine many separate measures of construct or variable to create a single score index is used to calculate (Neuman, 2007) 1, 2 and the 3 are three different types of scale used. Scale are a class of quantitative data measures often used in survey research that captures the intensity, direction level of a variable construct along continuum (Neuman, 2007). 
Table 3. Problems associated with production of seed in farmer's level $(n=70)$

\begin{tabular}{llccccc}
\hline \multirow{2}{*}{ Constraints } & \multicolumn{3}{c}{ Score* } & \multirow{2}{*}{ Total } & \multirow{2}{*}{ Index/Rank } \\
\cline { 2 - 4 } & 3 & 2 & 1 & & \\
\hline 1 & Unavailability of quality seed & 35 & 20 & 15 & 160 & 2.28 (I) \\
2 & Inadequate seed & 30 & 25 & 15 & 155 & 2.21 (III) \\
3 & Unaffordable price & 29 & 11 & 30 & 139 & 1.98 \\
4 & Inadequate storage structure & 25 & 30 & 15 & 150 & 2.14 (II) \\
5 & Not a demand driven variety & 28 & 20 & 22 & 146 & 0.22 \\
6 & No credit for crop insurance & 25 & 25 & 20 & 145 & 2.07 \\
7 & No subsidy for inputs & 26 & 20 & 16 & 134 & 1.91 \\
8 & Climatic calamities & 20 & 20 & 30 & 130 & 1.85 \\
9 & Inadequate training & 20 & 25 & 25 & 112 & 1.6 \\
\hline
\end{tabular}

* 1: Most problems, 2: Moderate Score 3: Least problem Source: Field survey, 2009

Till 2010 there are thirteen Seed Companies/cooperatives are working in the country. Mostly private companies in Chitwan district have been established in 2003/4 but till now mostly farmer are not in access to quality seed. Among various problems institutional problem associated to seed is categories below. Table four depicts the institutional problems relates to seed. Subsidies makes the farmers more dependent to other but untimely cutoff of the inputs sources may create havoc the example could be seen restart of fertilizer subsidy. Local development tax imposed by various places for the same product increase the cost of production. Insufficient Storage structures in institution as well the farm household decrease the quality of seed because as an orthodox nature of rice seed need optimum moisture percentage. This factor lead to confusion to farmers which seed should be used.

Table 4. Institutional problems associated with seed production

\begin{tabular}{|c|c|c|c|c|}
\hline \multirow{2}{*}{ Policy intervene } & \multicolumn{2}{|c|}{ Year } & \multirow{2}{*}{$\begin{array}{l}\text { Problems } \\
\text { associated }\end{array}$} & \multirow{2}{*}{ Remarks } \\
\hline & 2000 & 2010 & & \\
\hline Subsidy & $\sqrt{ }$ & $\mathrm{x}$ & \multirow{4}{*}{$\begin{array}{l}\text { Donors } \\
\text { pressure }\end{array}$} & a. $25 \%$ for the \\
\hline a. Seed & $\sqrt{ }$ & $\sqrt{ }$ & & DISSPRPO farmers \\
\hline b. Fertilizer & $\sqrt{ }$ & $\mathrm{x}$ & & b. (But discontinued \\
\hline c. Pesticide & & & & $\begin{array}{l}\text { for } 10 \text { years and now } \\
2.7 \% \text { subsidy has been } \\
\text { fixed. }\end{array}$ \\
\hline Buffer stock & $x$ & $\mathrm{x}$ & Financial & $\begin{array}{l}\text { Established in } 2000 \\
\text { but dropped. }\end{array}$ \\
\hline $\begin{array}{l}\text { Technical manpower } \\
\text { at right place }\end{array}$ & & & $\begin{array}{l}\text { Institutional } \\
\text { and policy }\end{array}$ & $\begin{array}{l}\text { Proper crop breeder } \\
\text { are }\end{array}$ \\
\hline
\end{tabular}




\begin{tabular}{lccll}
\hline \multicolumn{1}{c}{ Policy intervene } & \multicolumn{2}{c}{ Year } & $\begin{array}{c}\text { Problems } \\
\text { associated }\end{array}$ & Remarks \\
\cline { 2 - 4 } $\begin{array}{l}\text { Unorganized Pesticide } \\
\text { and insecticide }\end{array}$ & $\mathrm{x}$ & $\sqrt{ }$ & Policy & \\
entrepreneurship & & & & \\
Store & & & $\begin{array}{l}\text { Financial } \\
\text { Technical }\end{array}$ & To maintain moisture. \\
Agriculture reform fee & $\sqrt{ }$ & $\sqrt{ }$ & & \\
Local development tax & $\sqrt{ }$ & $\mathrm{x}$ & & \\
$\begin{array}{l}\text { Financial assistance } \\
\text { from providing credit }\end{array}$ & $\sqrt{ }$ & $\sqrt{ }$ & Policy & \\
$\begin{array}{l}\text { Havoc associated with } \\
\text { Political instability }\end{array}$ & & $\sqrt{ }$ & Policy & \\
\hline
\end{tabular}

\section{Conclusion}

Various disturbances in policy intervention make sluggishness to the seed system. It is observed in the policy level that untimely decided subsidy cut off is hitting directly and indirectly till now. Climatic effects are uncertain how and when a need could be felt. Therefore, need based research for demand driven variety is desired. Beside this, the demand of the Seed Company should be fulfilled to make assure timely availability of seed. There is a need to assure adequate financial assistance, timely technical guidance, and adequate supply of input materials, low cost storage structure, extension and training of recent technical developments.

\section{Acknowledgements}

The authors are highly thankful to IRRI for providing financial support for the study. Encouragement provided by the Chief of SARPOD, Dr.Yuga Nath Ghimire is highly acknowledged.

\section{References}

CBS (Central Bureau of Statistics). 2008. Statistical information book. 2008. Ministry of Agriculture and Cooperative.

Gauchan, D, A Subedi, SN Vaidya, MP Upadhyay, BK Baniya, DK Rijal and P Chaudhary. 1999. National policy and its implication for agro biodiversity conservation and utilization in Nepal. In: NP Working Paper No. 1/99. A scientific basis of in situ conservation of agro biodiversity on farm: Nepal's contribution to the global project. NARC's contribution to the global project. NARC, -BIRD and IPGRI. Pp. 111-128.

Neuman, WL. 2007. Qualitative and quantitative measurement. In: Social Research Methods. Qualitative and Quantitative Approaches. Sixth Edition. Pp: 179-218. 
Turner, M. 2010. The role of national seed policies in re-structuring the seed sectors in CEEC, CIS and other countries in transition. Accessed on 19 December 2010 from http://www.fao. org/docrep Downloaded on 12/19/2010.

Upreti, HKS, Bista, SN Sah, RC Prasad, R Dhakal. 2009. Khumal 8: a high-yielding variety with good cooking quality for the mid-hill areas of Nepal. Accessed in 2 January 2011 from http://beta.irri.org/publications Downloaded on 3 January 2011.

Sapkota, S, MN Paudel, NS Thakur, MB Nepali and R Neupane. 2010. Effect of climate change on rice production: A case of six VDCs in Jumla district. Nepal Jr. of Sci. and Tech. 11: 51-57

Sapkota, S, NS Thakur, MB Nepali, B Tripathi, S Pandey, D Gauchan, and P Regmi. 2010. Role of institutions for timely availability of quality seed of rice. Poster presented in the third international rice conference, 8-12, November, 2010. Hanoi, Vietnam.

Sapkota, S, J Bajracharya, D Gauchan and S Pandey. 2010. How seed system works to avail the quality seed of rice in Nepal. In:Paper presented at the Ninth National Outreach Workshop, 7-8 June, 2010, Khumaltar Nepal. In:Min Nath Paudel, Tanka Prasad Barakoti, Yuga Nath Ghimire(eds.), Nepal Agricultural Research Council, Kathmandu, Nepal.

Timsina, KP and PP Regmi. 2009. Poduction and marketing dynamics of milk: A case study of Chitwan districts, Nepal. J.Inst.Agric. and Anim.Sci. 30: 33-43. 